\title{
Pierre Briant, Kings, Countries, Peoples: Selected Studies on the Achaemenid Empire, translated by Amélie Kuhrt (Oriens et Occidens 26), Franz Steiner Verlag, Stuttgart 2017, 633 pp., 25 fig., ISBN 978-3-515-11628-2
}

The name Pierre Briant is known to almost every researcher of the history of the Hellenistic world, as well as of the history of Iran under Achaemenid rule. Owing to the originality of his interpretations and conclusions, for several decades every one of his articles has been the subject of intense interest. The problem is that not all of them reach the people who might get the most out of them. The readership is limited by the fact that Briant publishes most of his work in French as well as in the proceedings of the numerous conferences in which he participates, which often makes them difficult to access. Only some articles, published in journals, are available through JSTOR, Academia.edu and the Persée portal. A considerably larger hurdle in their reception, it would appear, is the language barrier, since non-Francophone scholars of the younger generation tend to have only limited familiarity with French. Sometimes this barrier can be overcome through translation into other languages, yet this method is usually confined to monographs, and seldom applied to collected studies. However, examples can be cited to confirm that an exception may be made for such volumes. One such book is this recently published collection of 28 studies by Briant translated from French into English by Amélie Kuhrt. The volume contains articles from 1979 to 2008, of which some 23 saw the light of day only in the 1990s and 2000s. No amendments, corrections or supplements have been made to the original texts. Only in one case, owing to the length of the French version, did the author decide to include only the final part in the collection (p. 2).

To provide a better oversight of the contents, almost all the studies are sorted into one of five subject areas, with the title of each one corresponding to the author's various research interests. This division is certainly useful, but a closer inspection of the contents of each section leads to the reflection that it is not as clear as it might seem. The main ideas running through all the studies are outlined in the article Central Power and Cultural Polycentrism in the Achaemenid Empire (pp. 43-73), which is the introduction to the volume. There are three texts in the first section, titled "Achaemenid Asia Minor:" Droaphernes and the Sardis Statue, pp.77-98; Cities and Satraps in the Achaemenid Empire: Xanthos and Pixodaros, pp. 99-127; The History and Archaeology of a Text: The Letter of Darius to Gadata between Persians, Greeks and Romans, pp. 128-166. The second, "Achaemenid Egypt," contains five: The Ruling Class and Subject Populations in the Achaemenid Empire: The Egyptian example, pp. 169-206; A Strange Affair at Elephantine in 410 B.C. Widranga, the Sanctuary of Khnûm and the Temple of Yahweh, pp. 207-220; When Kings write History: The Persian Period in Ptolemaic Inscriptions, pp. 221-231; Multilingual Inscriptions of the Achaemenid Period: Text and Image, pp. 232-248; Herodotus, Udjahorresnet and Darius'Palace at Susa, pp. 249-250. The 
third part, "The Great King, Land and Water" features some six articles (Sheep Breeding in the Achaemenid Empire (Sixth to Fourth Centuries B.C.), pp. 253-270; On the King as Gardener: Observations on the History of a Set of Documents, pp. 271-285; The Drinking Water of the Great King, pp. 286-304; Polybius X 28 and the qanāts: the Evidence and It Limitations, pp. 305-330; Montesquieu and his Sources: Alexander, the Persian Empire, the Guebres and Irrigation, pp. 331-344; The State, the Earth and Water between the Nile and Syr Darya, pp. 345-356), and the fourth, "Communication and Exchange," four: From Sardis to Susa, pp. 359-374; Themistocles on the Royal Road, pp. 375-376; [co-author R. Descat], A Customs Register from the Satrapy of Egypt in the Achaemenid Period (TAD C3,7), pp. 377-414; Tribute Payments and Exchange in Achaemenid and Hellenistic Asia Minor, pp. 415-425. The longest section is the fifth, "The Transition from the Achaemenid Empire to Alexander and the Hellenistic Kingdoms," with as many as nine texts: From the Achaemenids to the Hellenistic Rulers: Continuities and Changes, pp. 429-458; Michael Rostovtzeff and the Transition from the Achaemenid to the Hellenistic World, pp. 459-471; Greco-Hellenistic Sources, Persian and Macedonian Institutions: Continuities, Changes and 'bricolages', pp. 472-498; Alexander in Sardis, pp. 499-517; The Institutions of Achaemenid Sardis: An Additional Remark, p. 518; The Iranians of Asia Minor after the Fall of the Achaemenid Empire: The Amyzon Inscription, pp. 519-541; From Sardis to Persepolis: The Royal Economy between Private and Public, pp. 542-555; Asia Minor in Transition, pp. 556-589; The katarraktai of the Tigris: Irrigation-works, Commerce and Shipping in Elam and Babylonia from Darius to Alexander, pp. 590-610. Looking at the content of parts three to five, it is easy to notice that many of the articles are closely related to those in the first two parts.

Although the texts contained in Kings, Countries, Peoples have been known for some time, the book will certainly attract readers' attention for various other reasons. It contains an extensive Foreword (pp. 1-39), providing a valuable commentary from the author on each of the articles. Written from the perspective of the time that has elapsed since their initial publication, it contains information on the circumstances in which some of them were written and the changes that they often underwent before taking the form known from the publication, as well as explaining the author's stance regarding criticism of his views, or furnishing sometimes important addenda and corrections to the opinions expressed in the individual texts. People interested in Briant's academic work will also find a complete bibliography of his publications here (as of the second half of 2016) (pp. ix-xxiv).

Republication of Briant's articles in English translation is an excellent publishing idea. Without any doubt, this new collection will very much please a large number of researchers interested in various aspects of the history of the Achaemenid Empire and the Hellenistic world. ${ }^{1}$ It gives the texts themselves a "second life" by substantially widening their readership, and also contributes to a more intensive reception of their author's views and opinions.

Edward Dąbrowa (Jagiellonian University in Kraków)

1 To date, two other collections of Briant's articles have been published, one in French (Rois, tribus et paysants. Études sur les formations tributuaires du Moyen-Orient ancien, Paris 1982), and one in Persian (Central Power and Cultural Polycentism in the Achaemenid Empire, Teheran 2008). The last collection contains papers published originally in French or in English. 